\title{
Titae
}

31 (2017) 215-239

Tomasz Twardziłowski

tomasztwardzilowski@gmail.com

\section{PERSPEKTYWY ROZWOJU \\ EKOLOGICZNEJ HERMENEUTYKI BIBLII}

Perspectives on the Development

of the Ecological Hermeneutics of the Bible

Celem niniejszego artykułu jest dostarczenie biblistom szerokiego spojrzenia na perspektywy rozwoju ekologicznej hermeneutyki Biblii. Obecnie to podejście interpretacyjne cieszy się ogromną popularnością. Autor zbada, czy jest to jedynie zjawisko krótkotrwałe czy też stanowi ważny trend w aktualnych badaniach. Współcześnie wyróżniamy trzy główne nurty hermeneutyki ekologicznej. Ich teoretyczne i metodologiczne założenia różnią się punktem wyjścia i osiąganymi rezultatami w biblijnej interpretacji. Najbardziej rozpowszechniona forma apologetyczna często upraszcza i deformuje znaczenie tekstu, nie dając przez to wiarygodnej odpowiedzi na pytania współczesnego czytelnika. Forma radykalna odchodzi od hermeneutyki w stronę dekonstrukcji Biblii i rekonstrukcji nowego, hipotetycznego tekstu. Forma neoortodoksyjna rokuje najlepsze nadzieje na dalszy rozwój

hermeneutyka ekologiczna; ekologia; ekoteologia 
tego podejścia. Pozwala odkrywać bogactwo samego tekstu i tradycji jego interpretacji oraz poszukiwać w tekście podstaw lepszego rozumienia właściwej relacji człowieka ze stworzonym światem, w którym żyje i ma zostać zbawiony. Pozostaje mieć nadzieję, że proponowane studium poszerzy horyzonty badawcze w polskiej egzegezie.

Abstract

The aim of this article is to provide biblical scholars with a broad framework concerning the emerging field of "ecological hermeneutics" of the Bible, a very popular approach nowadays. This article examines whether it is only a temporarily fashionable phenomenon or a truly important trend for current and future research. There are presently three main streams of this interpretative approach, whose theoretical and methodological assumptions represent both different starting points and different objectives for biblical interpretation. The most popular, the apologetic form, often simplifies and distorts the meaning of the text and fails to provide credible answers to the modern reader. The radical form departs from hermeneutics and moves toward the deconstruction of the Bible and the reconstruction of a hypothetical biblical text. The neo-orthodox (revisionist) form is judged the most promising for the further development of ecological hermeneutics, as it allows exploration of the multitude of meanings of the biblical text and also of the traditions of its interpretation. It is a useful tool in the search for a better understanding of the proper relationship of man with the created world - the world in which he lives, is to be saved
KEYWORDS

Ecological hermeneutics; Ecology; Ecotheology 
and which he is called to protect. It is hoped that the proposed study will help expand the research horizons of Polish exegesis.

\section{WstęP}

Wymiernym owocem intensywnego rozwoju nauk biblijnych na przełomie XX i XXI wieku są nowe podejścia i metody egzegetyczne, a wraz z nimi ogromna liczba monografii, komentarzy i artykułów im poświęconych. Ożywienie badań biblijnych jest niewątpliwie związane z głębokimi zmianami społeczno-politycznymi oraz „wiosną biblijną”, która, zwłaszcza w biblistyce katolickiej, nastąpiła po Soborze Watykańskim II. Objętość materiału i różnorodność stanowisk, nierzadko sprzecznych, paradoksalnie mogą być odbierane nie jako pomoc, lecz jako przeszkoda w zrozumieniu sensu Pisma Świętego. Papieska Komisja Biblijna w dokumencie Interpretacja Biblii w Kościele wprawdzie zachęca biblistów katolickich do uwzględniania w swoich badaniach nowych metod i podejść, jednakże ich różnorodność w sposób nieuchronny prowadzi do pytania, czy wszystkie nowe rozwiązania są rzeczywiście potrzebne?

Zamieszczone refleksje naukowe poświęcone hermeneutyce ekologicznej będą obejmować cztery etapy. W części pierwszej nastąpi próba uporządkowania kwestii terminologicznych. W w części drugiej zostanie określona skala problemu i nastąpi rozstrzygnięcie, czy obfitość literatury na temat Biblii i ekologii świadczy wyłącznie o panującej modzie, a hermeneutyka ekologiczna stanowi jedynie nurt poboczny, czy też faktycznie podejście to odgrywa istotną rolę w interpretacji Pisma Świętego. Część trzecia zawierać będzie krytyczną analizę nurtów hermeneutyki ekologicznej, ich możliwości oraz skutków aplikacji do tekstów biblijnych. Część czwarta, obejmująca perspektywy rysujące się przed hermeneutyką 
ekologiczną, będzie zarazem próbą odpowiedzi na pytanie o metodologiczną zasadność tego podejścia i jego zgodność $\mathrm{z}$ hermeneutyką wiary, co powinno pozwolić ocenić, na ile jest ono zdolne do ponownego odczytania Pisma Świętego we współczesnym kontekście.

\section{Potrzeba uporząidKowania definicji HERMENEUTYKI EKOLOGICZNEJ}

Hermeneutykę ekologiczną definiuje się jako sposób odczytywania tekstów biblijnych z perspektywy ekologicznej. Samo wyrażenie "hermeneutyka ekologiczna” (ang. ecological hermeneutics) pojawiło się w drugiej połowie XX wieku w kontekście praktycznej troski o środowisko naturalne ${ }^{1}$. Do interpretacji Pisma Świętego zaczęli odnosić je pod koniec lat dziewięćdziesiątych XX wieku australijscy badacze pracujący pod kierunkiem Normana C. Habla, którzy rozpoczęli prace nad projektem The Earth Bible. Paletę określeń stosowanych zamiennie stanowią: „hermeneutyka ekosprawiedliwości” (ang. ecojustice hermeneutics), „hermeneutyka środowiskowa” (ang. environmental hermeneutics), „lektura ekologiczna” (ang. ecological reading), ,krytyka ekologiczna” (ang. ecological criticism).

Użycie terminu „hermeneutyka” w określeniu „hermeneutyka ekologiczna" budzi wiele kontrowersji. W odróżnieniu od wąskiego rozumienia tego terminu przez uczonych kontynentalnych, w świecie anglojęzycznym zauważalna jest tendencja do nadużywania i manipulacji tym terminem, co budzić może uzasadnione zastrzeżenia. Rzadko jednak zwraca się uwagę na fakt, że w języku angielskim hermeneutics

1 Wyrażenia „hermeneutyka ekologiczna” (wł. ermeneutica ecologica) użył Antonio Faeti w 1983 r. w odniesieniu do troski o środowisko naturalne przejawiającej się w utylizacji odpadów w spalarniach śmieci. Por. Faeti, La „camera” dei bambini, 180. 
to systematyczna refleksja nad praktyką interpretacji, czyli nad hermeneutic. Za jego odpowiedniki uznaje się terminy: „interpretacja” (ang. interpretation), „podejście” (ang. approach) czy „lektura” (ang. reading)2. Podejmując ten problem, Ernst M. Conradie zaproponował, by w ślad za myślą teologii liberacjonistycznej i feministycznej rozróżniać między interpretacją mającą aspekt praktyczny a hermeneutyką rozumianą jako teoria interpretacji, umieszczając tę ostatnią na drugim planie ${ }^{3}$. W praktyce bowiem refleksja w ramach omawianego podejścia dotyczy raczej sposobów odnajdywania w tekście przesłania związanego z szeroko pojmowaną ekologią i wyprowadzania z niego praktycznych wskazówek dla wierzących. W środowisku naukowym dyskusja na temat rozumienia hermeneutyki i określenia, czym ona się zajmuje, jest nadal żywotna i nie można spodziewać się jej szybkiego zakończenia.

Także drugi człon wyrażenia „,hermeneutyka ekologiczna”

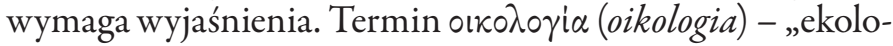
gia" - został utworzony z dwóch greckich terminów: oíkos

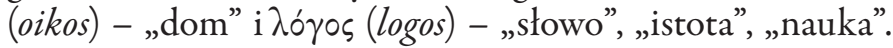
Połączenie w nowo utworzonym terminie znaczenia filozoficznego i ideologicznego z przyrodniczym było zamierzone przez Ernsta Haeckela (1834-1919), który definiował ekologię jako naukę o ekonomii, sposobie życia i zewnętrznych stosunkach witalnych między organizmami ${ }^{4}$, a następnie jako naukę o całości stosunku ustrojów do otaczającego świata przy precyzacji, że obejmuje ona stosunki między ustrojami

2 Warto w tym miejscu odnotować, że chociaż od ogłoszenia dokumentu Interpretacja Biblii w Kościele minęło 25 lat, rozstrzygnięcie, czym jest metoda, a czym podejście, wciąż stanowi przedmiot dyskusji. Ostatnio przypomnieli o tym polscy bibliści R. Bartnicki i W. Chrostowski. Por. Bartnicki, „Czym jest podejście”, 204-205; Chrostowski, "Zarys metodologii biblistyki”, 30; Chrostowski, „Kwestie terminologiczne w egzegezie biblijnej”, 207-208.

Por. Conradie, „What on Earth”, 296-297.

4 Por. Haeckel, Generelle Morphologie der Organismen, II, 8. 
żyjącymi w tym samym miejscu Ziemi, które determinuje walka o byt ${ }^{5}$. Zamiennie nazywał ją ekonomią, bionomią lub etologią. Choć Stanisław Zięba wyraził nieco na wyrost obawę, że E. Haeckel sam do końca nie wiedział, co właściwie powinno być przedmiotem badań ekologii ${ }^{6}$, można przyjąć, że z pewnością nie przewidywał, jakiemu poszerzeniu ulegnie pole semantyczne utworzonego terminu.

Aktualnie przyjmuje się, że ekologia jest nauką interdyscyplinarną i jako taka bazuje ona na wynikach badań innych nauk przyrodniczych: botaniki, zoologii, mikrobiologii, genetyki, etologii, fizjologii, chemii, fizyki, geografii, geologii, gleboznawstwa, oceanografii, meteorologii, klimatologii, ale też odwołuje się do nauk humanistycznych i społecznych: ekonomii, demografii, socjologii, psychologii, a nawet teologii ${ }^{7}$.

Bardziej popularne jest jednak potoczne rozumienie ekologii jako troski o środowisko naturalne. Przy takiej interpretacji zakres ekologii wykracza daleko poza ochronę przyrody. To rozumienie ekologii jest powszechne w skali globalnej, a ponadto społecznie akceptowalne. Rozwinęło się ono w drugiej połowie XX wieku, kiedy na fali ruchów kontestacyjnych zaczęto interesować się relacją człowieka do świata stworzonego i ochroną środowiska przed dewastacją ze strony człowieka. Próby redefinicji czy też przywrócenia właściwego rozumienia terminu „ekologia”, choć merytorycznie uzasadnione, także w środowisku polskim, gdzie nieoceniony wkład wniósł zwłaszcza Józef M. Dołęga i jego sozologia oraz ekofilozofia ${ }^{8}$, jak dotąd nie przyniosły oczekiwanych rezultatów, ustępując przed presją społeczną. Należy zatem podkreślić, że wyrażenie „hermeneutyka ekologiczna” bazuje na potocznym rozumieniu ekologii.

W tym miejscu poczyniona zostanie refleksja nad poprawnym brzmieniem nazwy analizowanego zjawiska w języku

5 Por. Haeckel, Natürliche Schöpfungsgeschichte, 777.

6 Por. Zięba, Historia myśli ekologicznej, 243.

7 Por. Ganowicz-Bączyk, Spór o etykę środowiskowa, 39.

8 Por. Dołęga, „Problematyka ochrony środowiska”, 19. 
polskim. Bez wątpienia w tłumaczeniu dosłownym ecological hermeneutics powinno brzmieć „hermeneutyka ekologiczna”, nie zaś „ekologiczna hermeneutyka”, co byłoby jedynie niepoprawną kalką językową. Rodzi się jednak pytanie o szyk słów w przypadku, gdy dodana zostaje przydawka dopełniaczowa precyzująca przedmiot badań. Z przeprowadzonych konsultacji wynika, że w tej kwestii stanowiska podzielone są między dwa logiczne rozwiązania. Za brzmieniem „hermeneutyka ekologiczna Biblii” stoi argumentacja, że przydawka przymiotna powinna znajdować się w postpozycji, jako wskazanie na cechę gatunkową (klasyfikującą). Stanowisko to jest słuszne o tyle, że w połączeniu rzeczownika z przydawką lepiej wypada szyk: rzeczownik, a po nim przymiotnik klasyfikujący (gatunkujący): „hermeneutyka ekologiczna”, „hermeneutyka feministyczna" itp. Przeciwne stanowisko zwraca uwagę na fakt, że w sytuacji gdy dodana zostaje jeszcze jedna przydawka, tym razem dopełniaczowa: „Biblii”, lepiej pierwszą przydawkę, przymiotnikową, przenieść przed rzeczownik, i dlatego z powodów czysto filologicznych należałoby opowiedzieć się za wersją „ekologiczna hermeneutyka Biblii" . Wobec tego wszędzie, gdzie nie została użyta przydawka dopełniaczowa, przydawka przymiotna powinna występować w postpozycji, a tam, gdzie wspomniana przydawka dopełniaczowa się pojawia, przydawka przymiotna powinna być użyta w prepozycji.

W celu uniknięcia nieporozumień oraz dla przejrzystości nazewnictwa należałoby zatem rozważyć stosowanie określeń eliminujących termin , hermeneutyka”, np. ,interpretacja ekologiczna”, „podejście ekologiczne” lub podobnych. Z drugiej

9 Andrzej Markowski wyjaśnia tę kwestię następująco: „O kolejności przydawek przymiotnych w zdaniu decydują ich cechy znaczeniowe oraz uwarunkowania kontekstowe. [...] 3. Przydawki klasyfikujące mogą stać przed wyrazem określanym, jeżeli: a) w zdaniu występuje także przydawka dopełniaczowa lub przyimkowa, np. Wyższa Szkota Biznesu, (ale: szkota wyższa), ekologiczny poradnik dla leśników, (ale: poradnik ekologiczny)". Markowski, Nowy stownik poprawnej polszczyzny, 1729. Por. Twardziłowski, Ocalić stworzenie, 55. 
jednak strony określenie „hermeneutyka ekologiczna” jako kalka z języka angielskiego jest samo w sobie zrozumiałe w sposób intuicyjny. Dlatego też każda zmiana terminologii powinna zostać poddana dyskusji w szerszym kręgu naukowym i być wynikiem konsensusu.

\section{RECEPCJA HERMENEUTYKI EKOLOGICZNEJ}

Hermeneutyka ekologiczna pojawiła się jako próba odpowiedzi egzegetów na wzmagający się kryzys ekologiczny. Odbierana jest często jako dość kontrowersyjna propozycja interpretacyjna, podobnie jak interpretacja feministyczna czy gender studies. Choć uchodzi za „nowinkę” w świecie biblistyki, nie jest zjawiskiem zupełnie nowym. Osiągnięcia obecnego pokolenia nie byłyby możliwe bez pionierskiego i prekursorskiego wysiłku poprzedników ${ }^{10}$.

Wyzwaniem dla tradycji chrześcijańskiej jest znalezienie wartościowej odpowiedzi na obecny w świecie kryzys. Ponieważ Biblia wciąż stanowi autorytet dla przeważającej części zarówno polskiego społeczeństwa, jak i ogółu ludzkości, odczytywane z niej przesłanie ma ogromne znaczenie dla kształtowania prawidłowych postaw społecznych. W ujęciu globalnym należy stwierdzić, że hermeneutyka ekologiczna rozwija się przede wszystkim w świecie anglojęzycznym. Szczególny wkład w jej rozwój wnieśli: Norman C. Habel, Peter Trudinger, Victoria Balabanski związani z University of Adelaide w Australii, David G. Horrell, Cherryl Hunt, i Christopher Southgate z University of Exeter w Wielkiej Brytanii oraz Ernst M. Conradie z University of Western Cape w Republice Południowej Afryki.

Ekologiczna hermeneutyka Biblii nie spotkała się, jak dotąd, z żywym zainteresowaniem środowiska naukowego

10 Por. Twardziłowski, „Wkład ekologicznej hermeneutyki Biblii”, 130-139. 
polskich biblistów, na co wskazuje niewielka liczba opracowań poddających rzeczowej analizie zagadnienia z nią związane. Nie została także uwzględniona w wydanych w ostatnim czasie metodologiach ${ }^{11}$. Uwarunkowania historyczne oraz sytuacja społeczno-polityczna odcisnęły na polskiej biblistyce niezatarte piętno, jednakże ani zestawianie jej z analogicznymi osiągnięciami w krajach zachodnich, ani przesadne, przesiąknięte niekiedy krytycyzmem, usprawiedliwianie opóźnień względem biblistyki światowej nie jest dla niej dobre. Triumfy popularności w polskiej teologii święcą natomiast ekoteologia i etyka środowiskowa, które wskazują na istotną wartość przyrody w stwórczym planie Boga ${ }^{12}$. Należy jednak pamiętać, że wartość merytoryczna tych prac jest zróżnicowana, a egzegeza w większości przypadków dokonywana jest w nich na podstawie tłumaczenia Biblii Tysiąclecia i dostępnych opracowań biblistycznych.

\section{Nurty ekologicznej hermeneUty ki Bibli i ICH OCENA}

Próbie oceny hermeneutyki ekologicznej towarzyszy charakterystyczne napięcie związane z ryzykiem popadania w skrajności. Z jednej strony jest to nadmierny optymizm prowadzący do bezkrytycznego przyjmowania tez bez rzetelnej analizy i podporządkowania wymaganiom i zaleceniom zawartym w dokumentach Kościoła. $Z$ drugiej strony zagrożenie stanowi przesadny sceptycyzm z charakterystycznym rysem apologetycznym i polemicznym przybierającym niekiedy formę sprzeciwu. Żadna z tych skrajności nie służy pogłębionej refleksji naukowej, która powinna przecież być

11 Por. Czerski, Metodologia Nowego Testamentu; Szymik, Wspótczesne modele egzegezy; Bartnicki, Kłósek, Metody interpretacji Nowego Testamentu.

12 Por. Babiński, „Ekoteologia jako odpowiedź”, 289-298; Sadowski, „Koncepcja ekosprawiedliwości”, 151-165. 
możliwie obiektywna. Oceny wydawane bez gruntownego zbadania i poznania hermeneutyki ekologicznej mogą być nie tylko przedwczesne, lecz także głęboko niesprawiedliwe.

Istotą zakorzenionego w Słowie Bożym światopoglądu chrześcijańskiego, a zarazem środkiem motywującym do kształtowania autentycznych relacji z Bogiem i drugim człowiekiem, jest wynikająca z Biblii prawda, że człowiek został stworzony na obraz Boży, odkupiony przez Syna i uświęcony przez Ducha Świętego. Pismo Święte od wieków stanowi szczególne źródło inspiracji, które pozwala ludziom przekraczać swoje ograniczenia i otwierać się na bogactwo tego wszystkiego, co Bóg mówi w swoim Słowie. To pragnienie pełnienia Bożej woli często przybiera formę egzystencjalnych pytań kierowanych pod adresem Pisma Świętego. Nie inaczej dzieje się w obliczu postępującej dewastacji środowiska naturalnego. Być może w łonie Kościoła katolickiego uznającego, że nierozdzielnym źródłem poznania Objawienia jest Pismo Święte i Tradycja ${ }^{13}$, intensywność tego zjawiska na pierwszy rzut oka nie jest tak zauważalna jak we wspólnotach protestanckich kierujących się zasadą sola scriptura i odrzucających Tradycję. Przypomnienie tej prawdy jest istotne dla zrozumienia genezy i kierunków rozwoju hermeneutyki ekologicznej, w ramach której można wyodrębnić różne nurty. Krytyczna ocena proponowanego przez nie sposobu odczytywania Pisma Świętego, która polegałaby na jasnym pokazaniu zalet i ograniczeń tego rodzaju interpretacji, nie jest sprawą łatwą, aczkolwiek nie niemożliwą. W tym celu należy skorzystać z pomocy i wskazówek zaoferowanych w dokumencie Interpretacja Biblii w Kościele, a zwłaszcza zastosować przedstawione tam kryteria oceny podejść kontekstualnych.

13 Por. KKK, nr 80, Sobór Watykański II, Konstytucja Dei Verbum, nr 40. 


\subsection{Nurt apologetyczny}

Nurt apologetyczny stanowił pierwszą odpowiedź na zarzuty pod adresem Biblii o jej przyczynienie się do kryzysu ekologicznego. Wiele ze słynnych tez Lynna White'a Jr. ${ }^{14}$ zasługiwało na uwagę, jednakże silnie polemiczny kontekst kontrowersji światopoglądowych końca lat sześćdziesiątych sprawiał, że były one przyjmowane nieufnie nie tylko wśród biblistów katolickich, lecz także protestanckich. Nie dziwi więc fakt, że to właśnie forma apologetyczna jest najbardziej popularna w działalności większości egzegetów i teologów odnoszących się do kwestii ekologicznej, nie wyłączając polskich biblistów.

Osiągnięciem tego nurtu jest koncepcja gospodarowania (ang. stewardship) zobowiązująca ludzi do odpowiedzialnej troski o stworzenie i wskazująca na konieczność zachowania równowagi pomiędzy ochroną środowiska naturalnego a korzystaniem z jego zasobów. Dość szybko stała się ona popularna zarówno wśród teologów, jak i wspólnot kościelnych, wprowadzając na stałe troskę o stworzenie do chrześcijańskiej nauki społecznej. Owo gospodarowanie należy rozumieć w kategoriach służby człowieka względem świata stworzonego polegającej na sprawowaniu pieczy i odpowiedzialnym zarządzaniu realizowanym zgodnie z koncepcją zrównoważonego rozwoju. Propozycja ta nie wynika wprost z egzegezy Pisma Świętego, ale jest raczej owocem teologicznego namysłu nad jego znaczeniem. $Z$ perspektywy historiozbawczej stworzenie związane jest z Bożym planem miłości i można je rozumieć tylko jako dar pochodzący od Boga i wzywający do powszechnej komunii. Biblijne polecenie, by człowiek panował nad Ziemią (Rdz 1,26-28) powinno być rozumiane w kluczu, jakim jest harmonia całej wspólnoty boskich stworzeń. Praktycznym przykładem realizacji tej drogi może być stosowanie metod pozwalających na rozsądne

14 Por. White, „The Historical Roots”, 1203-1207. 
korzystanie z zasobów natury oraz stopniowe zmniejszanie zanieczyszczeń, co nie będzie możliwe bez przezwyciężania mitu nieskończonego postępu i konsumpcjonizmu.

Ekologia postrzegana jest w tym nurcie jako praktyczna realizacja koncepcji gospodarowania. Zagrożeniem jest jednak zbyt powierzchowne odczytanie znaczenia tekstów biblijnych oraz zbyt bezkrytyczne przyjmowanie współczesnych prądów myślowych, co prowadzi do niebezpieczeństwa przeszacowania potencjału ludzkości oraz nieuświadomionego stawiania jej w roli Boga. Nie bez znaczenia jest również ignorowanie, będącego wynikiem grzechu, braku równowagi w relacjach między człowiekiem a przyrodą. Ewidentną słabością tego nurtu jest założenie, że teksty biblijne zawierają łatwo dostrzegalne przesłanie ekologiczne, problematyczna zaś może być jedynie ich antropocentrycznie skrzywiona interpretacja, a w efekcie brak rzetelnej analizy tekstu oraz nieuwzględnianie wielowiekowej tradycji interpretacyjnej. Wskutek tego interpretacja ta posługuje się w toku argumentacji niepotwierdzonymi pogląamiami i założeniami, powiela nieadekwatne schematy i często okazuje się powierzchowna i stronnicza. $Z$ jednej strony pociąga to konieczność obrony tekstów, które nie przyjmują optyki ekologicznej, z drugiej natomiast rezultatem jest usprawiedliwianie dominacji człowieka nad przyrodą. Ostatecznie niesie ona ryzyko ulegania tendencjom fundamentalistycznym ograniczającym rzetelne poszukiwania naukowe oraz wykrzywiającym znaczenie tekstu Biblii.

\subsection{Nurt radykalny}

Prekursorami nurtu radykalnego byli Norman C. Habel z Flinders University w Adelajdzie (Australia) i jego współpracownicy skupieni wokół projektu The Earth Bible opublikowanego w pięciu tomach w latach 2000-2002 ${ }^{15}$ i kontynuujący

15 Tytuł zbioru „The Earth Bible” może sugerować, że jest to nowe wydanie Biblii. W rzeczywistości poszczególne tomy to monografie 
prace w sekcji hermeneutyki ekologicznej w $\mathrm{SBL}^{16}$ oraz w serii komentarzy „The Earth Bible Commentary Series” ${ }^{17}$.

Zwolennicy formy radykalnej, niezadowoleni z osiągnięć formy apologetycznej, toczą bój o zmianę postawy ludzi w relacji do Ziemi jako podmiotu w tekście biblijnym. Specyficznie pojmują autorytet Biblii - odżegnują się od natchnionego charakteru tekstu i stosowania języka teologicznego, dokonując tym samym gwałtu na autonomii tekstu przez narzucanie mu perspektywy geocentrycznej, której on nie zawiera. Nie stronią od dekonstrukcji i tworzenia hipotetycznych rekonstrukcji zakrawających o literaturę fantastyczną ${ }^{18}$. Nurt radykalny spotyka się z zasłużoną krytyką ze strony egzegetów poszukujących przesłania ekologicznego w Bibliii ${ }^{19}$. Nie da się ukryć, że wobec przyjęcia ideologicznych założeń następuje narzucenie tekstowi obcych mu kategorii i deformacja jego znaczenia. Zasady ekosprawiedliwości wypracowane w ramach tego nurtu zawierają radykalnie świecką wizję relacji pomiędzy ludźmi, pozostałymi stworzeniami i Stwórcą. Ich stosowanie stanowi cel sam w sobie i doprowadza do głębokich ingerencji w sam tekst, nie zaś do wydobycia jego eko-

zbiorowe: Readings from the Perspective of Earth; The Earth Story in Genesis; The Earth Story in Wisdom Traditions; The Earth Story in the Psalms; The Earth Story in the New Testament.

16 Sesje sekcji hermeneutyki ekologicznej w ramach sympozjów Society of Biblical Literature swój początek zawdzięczają prekursorom nurtu radykalnego, jednakże przyciągają także zwolenników innych form hermeneutyki ekologicznej, przez co w sposób naturalny stymulują ożywione dyskusje nad przyszłością tego podejścia. Część referatów z pierwszych sesji została opublikowana w monografii zbiorowej: Exploring Ecological Hermeneutics.

17 Dotychczas ukazały się następujące tomy: Habel, The Birth, the Curse; Trainor, About Earth's Child; Person Jr., Deuteronomy and Environmental Amnesia; Habel, Finding Wisdom in Nature; Rees, Voices of the Wilderness; Wainwright, Habitat, Human, and Holy; Tonstad, The Letter to the Romans. Kolejne tomy są w przygotowaniu.

18 Por. Twardziłowski, Ekologiczna hermeneutyka Biblii, 110-117.

19 Por. Dykesteen Nilsen - Solevag, „Expanding Ecological Hermeneutics", 671-672. 
logicznego przesłania. Wobec ideologicznego podejścia do tekstu niemożliwy staje się także postulowany dialog z naukami przyrodniczymi.

Nadużyciem jest przyjmowane bezkrytycznie założenie, że perspektywa antropocentryczna z definicji i w praktyce oznacza nieuwzględnienie perspektywy Ziemi. Zwolennicy tego nurtu podkreślają i akcentują pokrewieństwo człowieka z resztą społeczności Ziemi, jednak wydaje się, że w praktyce człowiek nie jest traktowany jak każde inne stworzenie funkcjonujące zgodnie ze swoją naturą. Podobnych wymagań dotyczących bardziej ekologicznego postępowania nie stawia się bowiem żadnemu innemu stworzeniu. Doskonale obrazuje to krytyka zwyczajów żywieniowych człowieka przy całkowitym zbywaniu milczeniem faktu, iż drapieżnictwo i mięsożerność w przyrodzie sązjawiskiem naturalnym i powszechnym. Innym zarzutem, z jakim należy się zmierzyć, jest przywiązywanie zbyt dużej wagi do skali zanieczyszczeń o pochodzeniu antropogennym przy ignorowaniu faktu, iż oprócz nich istnieje także wiele zanieczyszczeń o pochodzeniu całkowicie naturalnym, np. wybuchy wulkanów. Zwolennicy nurtu radykalnego, żądając od człowieka zrezygnowania z mięsożerności, świadomego ograniczenia swojej ekspansji, a także stawiania potrzeb Ziemi i zamieszkujących ją stworzeń ponad potrzeby ludzi, nieświadomie uznają wyjątkowość człowieka jako istoty rozumnej.

Do walorów nurtu radykalnego należy zaliczyć podkreślanie statusu człowieka jako stworzenia, które przynależy do całej ziemskiej społeczności, i wskazanie na wewnętrzną wartość poszczególnych elementów świata oraz fakt tworzenia przez nie wspólnoty bytów pozostających $\mathrm{w}$ wielowymiarowych relacjach i wpływających na siebie nawzajem. Nurt ten, kwestionując tradycyjne rozumienie tekstu oraz postawy człowieka wobec Ziemi, oferuje punkt wyjścia do dostrzeżenia błędnych, w istocie niezgodnych z nauką Jezusa, zachowań, które bez tego pozostałyby zakryte. Uwaga badaczy nastawionych ekologicznie skierowała się także na analizę kwestii 
wpływu antropocentryzmu na interpretację Biblii. Warto docenić, że zwolennicy nurtu radykalnego zwrócili uwagę na fragmenty biblijne, których dotychczas nie uwzględniano w kontekście ekologicznym (np. Mt 6,25-34; Mk 1,1-15; 13; J 1; Ef 1; Hbr 11).

\subsection{Nurt neoortodoksyjny (rewizjonistyczny)}

Ze względu na dotychczas osiągnięte rezultaty najlepiej rokuje forma neoortodoksyjna, zwana też rewizjonistyczną, gdyż proponuje rewizję chrześcijańskiej tradycji interpretacyjnej w kierunku większej wrażliwości na problemy ekologiczne. Wśród przedstawicieli tego nurtu znajdują się Denis Edwards, H. Paul Santmire oraz bibliści pracujący w Centre for Biblical Studies Uniwersytetu w Exeter pod kierownictwem Davida G. Horrella ${ }^{20}$. To forma neoortodoksyjna przedstawia integralne podejście do kwestii ekologicznych w egzegezie biblijnej i teologii. Nurt ten jest najbardziej zrównoważony w swoich sądach. Podejmuje krytyczną analizę tekstów celem odkrycia, jaki potencjał ekologiczny zawierają. Nie wskazuje w Biblii tekstów ekologicznie przyjaznych ani też antyekologicznych i przyjmuje, że każdą hipotezę należy zbadać, co w dwóch wcześniej omówionych nurtach nie było tak oczywiste. Nie ogranicza się też do jednej metody, względnie narzuconego odgórnie sposobu rozumienia treści, ale postuluje korzystanie ze znanych metod egzegetycznych

20 W latach 2006-2009 na Wydziale Teologii i Religii Uniwersytetu w Exeter (Wielka Brytania) zrealizowano projekt badawczy „Uses of the Bible in Environmental Ethics” finansowany przez Arts and Humanities Research Council, który zapewnia rządowe wsparcie dla prac naukowych w dziedzinie sztuki i nauk humanistycznych. Najważniejsze publikacje: Ecological Hermeneutics; Horrell - Hunt - Southgate, Greening Paul; Horrell, The Bible and the Environment. Pełna lista publikacji naukowych w ramach tego projektu dostępna jest pod adresem: http://humanities.exeter.ac.uk/theology/research/ projects/uses/publications/. 
w zależności od rodzaju badanego tekstu. Zadaniem badaczy jest uwzględnienie zarówno kontekstu czytelnika, jak i tekstu, a także bogatej tradycji biblijnej danego tekstu. Do tego konieczne jest wyjście od studium historycznego i rozwiniętej egzegezy umożliwiającej uważną analizę perykop biblijnych. Następnie należy odnieść się do nowego kontekstu w dialogu z dotychczasową tradycją interpretacyjną. Jest to forma pośrednia pomiędzy konserwatywną apologetyką i radykalnym rekonstrukcjonizmem. Rozwój konstruktywnej hermeneutyki ekologicznej wymaga także interdyscyplinarnej współpracy z innymi dziedzinami wiedzy zajmującymi się analizą problemów ekologicznych, jak np. etyka.

David G. Horrell zaproponował wyprowadzone z Biblii i uwzględniające lekturę kanoniczną klucze hermeneutyczne (dobroć stworzenia, przynależność ludzkości do wspólnoty stworzenia, współzależność losów człowieka i Ziemi, przymierze z całym stworzeniem, uwielbianie Boga przez stworzenie, wyzwolenie i pojednanie wszystkich rzeczy) ${ }^{21}$. Przede wszystkim uszanowanie religijnego charakteru tekstów biblijnych pozwala dostrzec pełne przesłanie Biblii i umożliwia ekologicznej hermeneutyce Biblii wyprowadzenie z tekstu wniosków, które będą w stanie doprowadzić do przemyślenia i przeformułowania doktryny, a co za tym idzie, także zmiany życia i sposobu postępowania wierzących. Proponowany klucz odczytywania tekstu biblijnego obejmuje dwojaką krytykę: chrześcijańską ewaluację podstawowych nawyków kultury podkreślającą zagrożenia ekologiczne i ekologiczną ewaluację chrześcijaństwa.

Wspólną cechą nurtów apologetycznego i neoortodoksyjnego jest próba przywrócenia tekstom ich ekologicznego potencjału znaczeniowego. Tworząca się wrażliwość ekologiczna przyczynia się do zdemaskowania i skorygowania pewnych zaakceptowanych już poglądów, w gruncie rzeczy jednak tendencyjnych i głęboko niesprawiedliwych, ta-

21 Por. Horrell, The Bible and the Environment, 129-136. 
kich jak: przekonanie, że człowiek jest panem stworzenia, traktowanie zwierząt jak towaru, priorytetowe traktowanie mięsożerności (wbrew prawdzie, że człowiek z natury jest istotą wszystkożerną), objęcie zbawieniem tylko ludzi czy przekonanie, że koniec świata związany będzie z kosmiczną katastrofą. Różnią się one drogą, która prowadzi do tego celu. Nurt apologetyczny, dążąc do ukazania ekologicznej wartości tekstu natchnionego i odzyskania (ang. recovery) jego sensu wypaczonego w długiej tradycji interpretacji, ogranicza zarazem jego znaczenie, nie pozwalając mu w pełni wybrzmieć. W ramach nurtu neoortodoksyjnego zaś chodzi o rzetelną analizę tekstu oraz tradycji jego interpretacji oświetloną przez pytania wynikające z sytuacji współczesnych czytelników. Hermeneutyka ekologiczna najlepiej spełnia postawione przed nią zadanie, gdy bierze pod uwagę specyfikę tekstów biblijnych - ich religijny charakter, kontekst historyczny, społeczny i kulturowy oraz wielowiekową tradycję interpretacyjną. Dlatego najbardziej obiecująca, jeżeli chodzi o szerokie zastosowanie w ekoteologii i praktyce duszpasterskiej, wydaje się być forma neoortodoksyjna.

\section{KIERUNKI ROZWOJU HERMENEUTYKI EKOLOGICZNEJ}

Ekologiczna hermeneutyka Biblii klasyfikowana jako jedno ze współczesnych kontekstualnych podejść do tekstu biblijnego, począwszy od swego specyficznego punktu widzenia, praktykuje pewną światopoglądowo nacechowaną interpretację Biblii. Zasadność tego przyporządkowania potwierdza fakt, że podejścia liberacjonistyczne i feministyczne łączy z podejściem ekologicznym wspólny punkt wyjścia, jakim jest doświadczenie ucisku w konkretnej sytuacji życiowej. Punktem docelowym zaś jest wynikająca stąd reinterpretacja zasadniczych celów uprawiania teologii. Uwzględnianie osobistego kontekstu oraz doświadczeń komentatorów prowadzi do ogromnej różnorodności wy- 
pracowanych stanowisk. Zasady stosowane w ekologicznej hermeneutyce Biblii są zbieżne z tymi stosowanymi w hermeneutyce feministycznej, ekofeminiści zaś dochodzą do wniosku, że niczym nieograniczona eksploatacja natury jest związana z patriarchalnym stosunkiem do kobiet w Biblii i tradycji chrześcijańskiej. Należy zauważyć, że zastosowanie zasad pochodzących z hermeneutyki feministycznej (takich jak podejrzenie i odzyskanie) do relacji ludzi z Ziemią niesie ze sobą znaczne trudności, szczególnie w zakresie identyfikacji z innymi bytami niebędącymi ludźmi.

Odczytywanie Pisma Swiętego z perspektywy ekologicznej nastawione jest na zastosowanie go we współczesnej etyce środowiskowej, dla której poszukuje się argumentacji w tekstach biblijnych. Takie podejście zawiera niewątpliwie elementy wartościowe, ale wiąże się też z brakiem hermeneutycznej neutralności. Egzegeza nie może być wprawdzie całkowicie neutralna hermeneutycznie, egzegeci muszą jednak uważać, aby nie popaść w interpretacje jednostronne i naukowo nieweryfikowalne. Dotyczy to szczególnie radykalnego nurtu podejścia ekologicznego, w którym przyjęte zasady interpretacyjne są wyraźnie narzucane na tekst Pisma Świętego. Zadaniem dobrze pojętej hermeneutyki natomiast powinna być pomoc we właściwym rozumieniu tekstu Biblii stanowiącej źródło wiary i postępowania.

Dokument Papieskiej Komisji Biblijnej Interpretacja Biblii w Kościele z 1993 r. w odniesieniu do kontekstualnych podejść interpretacyjnych docenia uwzględnianą przez nie perspektywę pozwalającą egzegetom podjąć w badaniach "nowe punkty widzenia odpowiadające współczesnym prądom myślowym"22, przestrzegając jednocześnie, aby czynić to $\mathrm{z}$ rozeznaniem krytycznym. Hermeneutyka ekologiczna narażona jest na ryzyko lektury ideologicznej. Aby temu przeciwdziałać, należy podjąć trud weryfikowania podejmowanych sposobów interpretacji w oparciu o zasady hermeneu-

22 Papieska Komisja Biblijna, Interpretacja Biblii w Kościele, 50. 
tyki biblijnej, a zwłaszcza hermeneutyki wiary proponowanej przez papieża Benedykta XVI ${ }^{23}$. Pozwoli to na poszerzenie spektrum podejść do tekstu Pisma Świętego i podjęcie próby odpowiedzi na współczesne problemy człowieka z jednoczesnym uwzględnieniem perspektywy wiary. To współczesne podejście interpretacyjne wykracza daleko poza egzegezę biblijną i ma naturę interdyscyplinarną. Poprzez uwzględnienie problemów związanych ze współczesnym kryzysem ekologicznym może odsłonić interesujące perspektywy badawcze i pogłębić naukową refleksję nad Biblią, a także ubogacić życie duchowe czytelników, ukazując świeże spojrzenie na problemy codzienności.

Przez aplikację do tekstu biblijnego nowych pytań, podejście ekologiczne dąży do przekroczenia dystansu historycznego i kulturowego, jaki dzieli świat powstania Biblii od świata jej dzisiejszych odbiorców. Nie może jednak lekceważyć świata tekstu i jego teologicznej złożoności. Cenne mogą się tu okazać wskazówki dokumentu Interpretacja Biblii w Kościele odnośnie do lektury duchowej i aktualizacji przesłania biblijnego. Rzetelna analiza egzegetyczna tekstu i odkrycie sensu dosłownego powinny być traktowane jako punkt wyjścia dla lektury duchowej, która musi uwzględniać zarówno kontekst całości Objawienia, jak i szeroko pojętego życia Kościoła. Taka lektura pozwala tekstowi biblijnemu ujawnić swój charakter, wyjątkowy i inny niż odczytują współczesne teorie ekologiczne, a czytelnikowi wskazać, jakie zasady ekosprawiedliwości mogą zostać wyprowadzone z tekstu Biblii. W ten sposób ekologiczna hermeneutyka Biblii może wpisać się w biblijną tradycję interpretacyjną, stając się jej integralną częścią. Ekologia środowiska musi pozostawać w ścisłym związku z ekologią człowieka. Dostrzeżenie ekologicznej wartości tekstu Biblii poszerza spojrzenie na relację człowieka ze środowiskiem naturalnym, pomaga zdemaskować i usunąć rozpowszechnione tendencyjne interpretacje

23 Por. Benedykt XVI, Verbum Domini, nr 19, 29, 31. 
uzasadniające bezwzględną dominację ludzi nad naturą. Jednakże nie wszystkie zniszczenia w świecie stworzonym zależą od działalności człowieka. Nie można więc wskazać na ludzkość jako jedyne czy główne źródło zła i zniszczenia $\mathrm{w}$ środowisku naturalnym, żądając jako remedium ograniczenia lub usunięcia rodzaju ludzkiego. Stworzenie na obraz i podobieństwo Boga jest wezwaniem do współpracy z Bogiem i realizowania tego podobieństwa na co dzień. Początkiem eschatologicznej przemiany całego stworzenia jest wydarzenie śmierci i zmartwychwstania Chrystusa, Pierworodnego spośród umarłych (Kol 1,18) i Pierworodnego wobec wszelkiego stworzenia (Kol 1,15). Pojednanie wszystkiego w Chrystusie dotyczy także pojednania człowieka ze stworzeniem, a jego realizacja w doczesności jest zadaniem Kościoła.

Ze względu na nieprzerwany, dynamiczny rozwój hermeneutyki ekologicznej trudno wyrokować w kwestii jej przyszłości. Warto zintensyfikować badania w celu odkrycia, jakie konsekwencje doktrynalne, moralne, światopoglądowe i społeczne niesie ona ze sobą. Hermeneutyka ekologiczna przyniesie owoce wówczas, gdy wyniki badań biblijnych znajdą odzwierciedlenie w badaniach teologów systematycznych i praktycznych, potwierdzając spójność z depozytem wiary. Miejsce postaw skrajnych, zarówno antropocentrycznych, jak i biocentrycznych, powinna zająć hermeneutyka ekologiczna ukierunkowana teocentrycznie, która zaktualizuje przesłanie Pisma Świętego z uwzględnieniem Bożego planu dla Ziemi, tak by został przywrócony szacunek całemu dziełu stworzenia.

Pogłębienia wymaga jeszcze wiele zagadnień, takich jak: przywrócenie współczesnemu człowiekowi idei Boga jako Stwórcy i Pana świata stworzonego, rola i ograniczenia człowieka w relacjach ze światem przyrody, zakres odpowiedzialności i uznanie granic możliwości działania człowieka w jego relacjach z przyrodą, teocentryczne spojrzenie na ekologię, ponowne odkrycie roli piękna w relacji człowieka do świata stworzonego, reinterpretacja doktryny dotyczącej grzechu jako 
źródła zła w świecie stworzonym i zaburzenia relacji pomiędzy jego poszczególnymi elementami oraz pomiędzy całością stworzenia a Bogiem. Wyzwaniem dla hermeneutyki ekologicznej jest spojrzenie w szerszej perspektywie na zagadnienie kanoniczności i zestawienie tego, co zostało ujęte w kanonie Pisma Świętego, z tym, co nie zostało w nim uwzględnione, jako owoc świadomej decyzji wyrastającej z wiary Kościoła.

\section{ZAKOŃCZENIE}

Aktualne problemy ekologiczne i duże zainteresowanie rozmaicie rozumianą ekologią potwierdzają zasadność zajęcia się tą problematyką także w biblistyce. Celem tych dążeń winno być opracowanie odpowiedniego warsztatu metodologicznego dla teologii ekologicznej wraz ze wskazaniem nowych perspektyw, jakie to podejście może wnieść do interpretacji Biblii.

W łonie hermeneutyki ekologicznej występują nurty o charakterze negatywnym (forma radykalna) oraz pozytywnym (formy apologetyczna i rewizjonistyczna). Nurt radykalny nie mieści się w ramach hermeneutyki ani nawet interpretacji, gdyż jego celem jest polemika ze znaczeniem odkrywanym w tekście lub wręcz negacja pewnych aspektów przesłania tekstu biblijnego. Autorzy, najczęściej w sposób nieuświadomiony, wpisują się w apologetyczny nurt hermeneutyki ekologicznej. Na akceptację i uznanie zasługuje również rewizjonistyczna forma hermeneutyki ekologicznej.

Podsumowując, należy stwierdzić, że niewątpliwie dobrą stroną badań podjętych w ramach ekologicznej hermeneutyki Biblii jest budzenie świadomości ekologicznej wśród wierzących. Prowadzi to do przypomnienia na nowo wartości świata stworzonego jako dzieła Boga. Odpowiedzialność za dobrostan tego dzieła nie powinna ograniczać się jednak tylko do kultury opartej na wartościach judeochrześcijańskich. Ubogacający dialog z nauką, któremu przyświeca budowanie integralnej ekologii, powinien mieć wymiar międzyreligijny. 
Pozostaje mieć nadzieję, że także pozostałe święte teksty, które cieszą się autorytetem wśród wyznawców innych religii, zostaną poddane krytycznej analizie, podobnie jak ma to miejsce w ekologicznej hermeneutyce Biblii.

\section{BiBLIOGRAFIA}

Babiński J., „Ekoteologia jako odpowiedź na współczesny kryzys ekologiczny", Teologia w Polsce 5/2 (2011) 289-298.

Bartnicki R., „Czym jest podejście, a czym metoda?”, Collectanea Theologica 86/4 (2016) 203-206.

Bartnicki R. - Kłósek K., Metody interpretacji Nowego Testamentu.

Wprowadzenie (Kraków: Petrus 2014).

Benedykt XVI, Adhortacja Verbum Domini (2010).

Chrostowski W., „Zarys metodologii biblistyki Nowego Testamentu", Studia Nauk Teologicznych 2 (2007) 27-46.

Chrostowski W., ,Kwestie terminologiczne w egzegezie biblijnej”, Collectanea Theologica 86/4 (2016) 207-208.

Conradie E.M., „What on Earth is an Ecological Hermeneutics? Some Broad Parameters", Ecological Hermeneutics: Biblical, Historical and Theological Perspectives (red. D.G. Horrell C. Hunt - C Southgate - F. Stavrakopoulu) (London - New York, NY: T\&T Clark 2010) 296-313.

Czerski J., Metodologia Nowego Testamentu (Opolska Biblioteka Teologiczna 126; Opole: Redakcja Wydawnictw Wydziału Teologicznego Uniwersytetu Opolskiego 2012).

Dołęga J.M., „Problematyka ochrony środowiska społeczno-przyrodniczego w sozologii i ekofilozofii", Ochronaśrodowiska w filozofi i teologii (red. J.M. Dołęga - J.W. Czartoszewski) (Warszawa: Akademia Teologii Katolickiej 1999) 10-26.

Dykesteen Nilsen T. - Solevag A.R., „Expanding Ecological

Hermeneutics: The Case for Ecolonialism", Journal of Biblical Literature 135/4 (2016) 665-683.

The Earth Story in Genesis (red. N.C. Habel - S. Wurst) (The Earth Bible 2; Sheffield: Sheffield Academic Press 2000). 
The Earth Story in the New Testament (red. N.C. Habel -

V. Balabanski) (The Earth Bible 5; Sheffield: Sheffield Academic Press 2002).

The Earth Story in the Psalms and the Prophets (red. N.C. Habel)

(The Earth Bible 4; Sheffield: Sheffield Academic Press 2001). The Earth Story in Wisdom Traditions (red. N.C. Habel - S. Wurst)

(The Earth Bible 3; Sheffield: Sheffield Academic Press 2001). Ecological Hermeneutics: Biblical, Historical, and Theological

Perspectives (red. D.G. Horrell i in.) (London - New York,

NY: T\&T Clark 2010).

Exploring Ecological Hermeneutics (red. N.C. Habel - P. Trudinger)

(SBL.SympS 46; Atlanta: Society of Biblical Literature 2008).

Faeti A., La „camera” dei bambini: cinema, mass media, fumetti, educazione (Ombra Sonora 12; Bari: Dedalo 1983).

Ganowicz-Bączyk A., Spór o etykęśrodowiskowa (Kraków: WAM 2009).

Habel N.C., Finding Wisdom in Nature: An Eco-Wisdom Reading of the Book of Job (Earth Bible Commentary 4; Sheffield: Sheffield Academic Press 2014).

Habel N.C., The Birth, the Curse and the Greening of Earth: An Ecological Reading of Genesis 1-11 (Earth Bible Commentary 1; Sheffield: Sheffield Academic Press 2011).

Haeckel E., Generelle Morphologie der Organismen. Allgemeine Grundzüge der organischen Formen-Wissenschaft, mechanisch begründet durch die von Charles Darwin reformirte DescendenzTheorie (Berlin: G. Reimer 1866) II.

Haeckel E., Natürliche Schöpfungsgeschichte. Gemeinverständliche wissenschaftliche Vorträge über die Entwicklungslehre im Allgemeinen und diejenige von Darwin, Goethe und Lamarck im Besonderen, über die Anwendung derselben auf den Ursprung des Menschen und andere damit zusammenhängende Grundfragen der Naturwissenschaft (Berlin: G. Reimer 1868).

Horrell D.G., The Bible and the Environment: Towards a Critical, Ecological Biblical Theology (London - New York, NY: Equinox 2010). 
Horrell D.G. - Hunt C. - Southgate C., Greening Paul: Rereading the Apostle in an Age of Ecological Crisis (Waco, TX: Baylor University Press 2010).

Markowski A., Nowy stownik poprawnej polszczyzny (Warszawa: PWN 2002).

Papieska Komisja Biblijna, „Interpretacja Biblii w Kościele”, Interpretacja Biblii w Kościele. Dokument Papieskiej Komisji Biblijnej z komentarzem biblistów polskich (red. R. Rubinkiewicz) (RSB 4; Warszawa: Vocatio 1999) 24-100.

Person R.F. Jr., Deuteronomy and Environmental Amnesia (Earth Bible Commentary 3; Sheffield: Sheffield Academic Press 2014). Readings from the Perspective of Earth (red. N.C. Habel) (The Earth Bible 1; Sheffield: Sheffield Academic Press 2000).

Rees A., Voices of the Wilderness: An Ecological Reading of the Book of Numbers (Earth Bible Commentary 5; Sheffield: Sheffield Academic Press 2015).

Sadowski R.F., „Koncepcja ekosprawiedliwości w encyklice Laudato si'”, Roczniki Teologiczne 63/3 (2016) 151-166.

Szymik S., Wspótczesne modele egzegezy biblijnej (Lublin:

Wydawnictwo KUL 2013).

Tonstad S.K., The Letter to the Romans: Paul among the Ecologists (Earth Bible Commentary 7; Sheffield: Sheffield Academic Press 2016).

Trainor M., About Earth's Child: An Ecological Listening to the Gospel of Luke (Earth Bible Commentary 2; Sheffield: Sheffield Academic Press 2012).

Twardziłowski T., „Wkład ekologicznej hermeneutyki Biblii w budowanie prawidłowych relacji społeczności ludzkiej ze środowiskiem naturalnym”, Kwartalnik Naukowy „Fides et ratio" 22/2 (2015) 130-139.

Twardziłowski T., Ekologiczna hermeneutyka Biblii: cele, rezultaty, zastosowania (Warszawa: Wydawnictwo Uniwersytetu Kardynała Stefana Wyszyńskiego 2015).

Twardziłowski T., Ocalić stworzenie. Teoria i zastosowanie ekologicznej hermeneutyki Biblii (Warszawa: Instytut Papieża Jana Pawła II 2017). 
Wainwright E.M., Habitat, Human, and Holy: An Eco-Rhetorical Reading of the Gospel of Matthew (Earth Bible Commentary 6; Sheffield: Sheffield Academic Press 2016).

White L.T. Jr., „The Historical Roots of Our Ecologic Crisis”, Science 155 (1967) 1203-1207.

Zięba S., Historia myśli ekologicznej (Lublin: Wydawnictwo KUL 2004).

Tomasz TwardziŁowsKi, doktor teologii biblijnej, absolwent Uniwersytetu Kardynała Stefana Wyszyńskiego w Warszawie. W latach 2014-2015 zrealizował projekt badawczy Ekologiczna hermeneutyka Biblii: cele, zatożenia, rezultaty, zastosowania. Projekt został sfinansowany ze środków Narodowego Centrum Nauki przyznanych na podstawie decyzji numer DEC-2013/09/N/ HS1/03628. Opublikował monografie Ekologiczna hermeneutyka Biblii: Cele, rezultaty, zastosowania (Warszawa: Wydawnictwo Uniwersytetu Kardynała Stefana Wyszyńskiego 2015) oraz Ocalić stworzenie. Teoria i zastosowanie ekologicznej hermeneutyki Biblii (Warszawa: Instytut Papieża Jana Pawła II 2017). 